\title{
POPULATION STUDIES IN DUPUYTREN'S CONTRACTURE
}

\author{
P. F. Early, Manchester, England
}

From the Department of Orthopaedic Surgery, Manchester Roval Infirmary

The demography of Dupuytren's contracture, as of many other chronic diseases, has hitherto received little attention. From time to time over the past eighty years figures have appeared in the literature of several countries purporting to show the incidence of the contracture. But many of these figures are useless, either because the population sample was a selected one or because its age distribution was not stated, or even because the sexes were not considered separately. In others it is uncertain from the data whether all stages of contracture were included, or only cases showing flexion deformity of one or more digits. The one statistical fact upon which all writers are agreed is the increasing incidence of the contracture with age: yet few authors give even an average age or age-range for the populations investigated, and fewer still have analysed their results by age groups. Thus there is a need for further surveys on a scale large enough to allow statistical analysis, using methods sufficiently standardised to enable comparisons to be made with the findings of other workers.

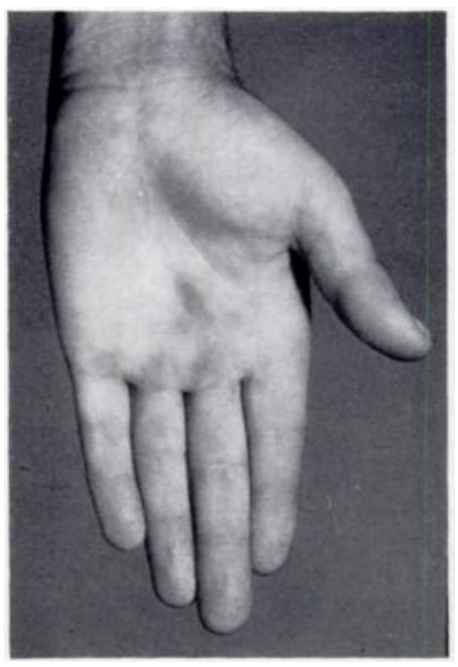

Fig. 1

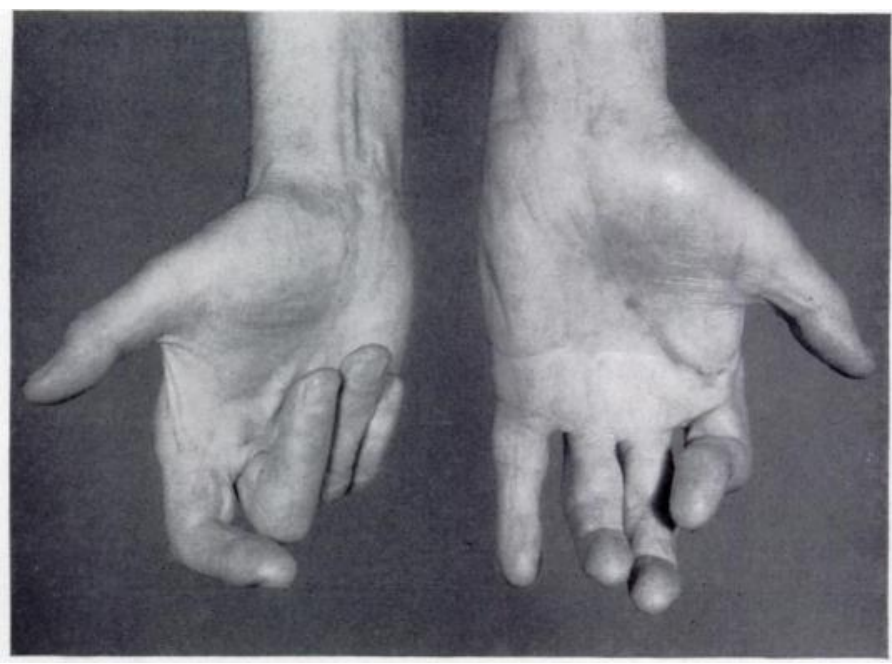

FIG. 2

Figure 1-Early palmar nodule without finger contracture (Stage 0) in a man aged thirty, with a two-year history. Figure 2-Advanced bilateral contracture in a man aged sixty-one. The left hand, with a five-year history, is at Stage III; the right hand with a twenty-six-year history is at Stage IV. Note the hyperextension deformity of left index finger.

The purpose of this paper is to report on the prevalence of Dupuytren's contracture in the Manchester area, and to investigate its relationship to occupation and to certain diseases with which an association has, in the past, been claimed. Finally, the distribution of this contracture in the world at large is discussed, within the limitations of the available evidence.

\section{METHOD AND MATERIAL}

The diagnosis of Dupuytren's contracture is, with few exceptions, readily made on inspection and palpation of the palms and fingers. In this paper the material to be described includes all stages from the isolated palmar nodule without finger contracture (Fig. 1) to the severest deformities (Fig. 2). The system of staging used here depends upon both the number 
of deformed fingers and the degree of flexion in each, as measured by a protractor, and divides hands into five stages from 0 to IV. Points are allotted to each contracted digit according to the sum of the degrees of flexion-or occasionally, in the distal interphalangeal joint, of hyperextension-deformity in its separate joints:

Digital deformity 60 degrees or less . . . 1 point

Digital deformity over 60 degrees, up to 120 degrees 2 points

Digital deformity over 120 degrees. . . . 3 points

A score for the hand is then reached by the addition of these points. Staging of the hand depends on its score, thus:

$$
\begin{aligned}
& \text { Score } 0 \text {. . Stage } 0 \quad \text { Score } 2 \text { or } 3 \text {. Stage II } \\
& \text { Score 1. . Stage I Score } 4,5 \text { or } 6 \text {. Stage III } \\
& \text { Score } 7 \text { or more . . Stage IV }
\end{aligned}
$$

For the present study, surveys have been made of the employees at a large engineering works; of the residents of a home for old people; of a cross-section of the population of Leigh, a Lancashire industrial and mining town; and of the patients in an epileptic colony. Additional data are drawn from a series of nearly four hundred cases of Dupuytren's contracture seen at hospitals in and around Manchester.

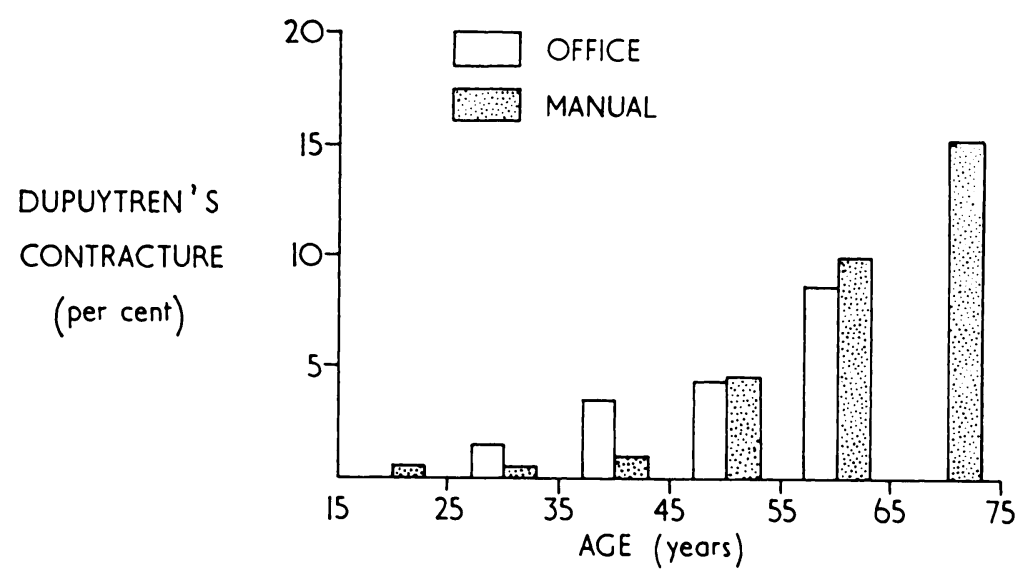

Fig. 3

Incidence of Dupuytren's contracture in male office and manual workers at Crewe locomotive works.

Dupuytren's contracture in a working community - Chronic occupational injury has commonly been supposed to contribute to the occurrence of Dupuytren's contracture, notably by Dupuytren himself (1832), but statistical evidence supporting this theory is scanty (Collis and Eatock 1912, Niederland 1933, Schröder 1934). In order to discover the frequency of palmar contracture in an active working population, and the influence on it, if any, of occupation, the hands of some five thousand staff and day-shift employees at the Crewe locomotive works were examined. Most of those examined were men, and their incidence of contracture varied from 1 in 1,000 for the age group fifteen to twenty-four to 15 per cent in those over sixty-five (Table I). A separate analysis of office and manual workers (Table II, Fig. 3) shows no significant difference between the two: the overall frequency works out at 4.0 per cent in office staff, and 3.3 per cent in manual workers. This confirms the findings of Herzog (1951) who reported nearly equal contracture rates among steel workers, miners and clerks (one thousand of each) whom he examined in Rotherham, Sheffield and Manchester. Hueston (1960) reached a similar conclusion and, indeed, suggested that decreased hand activity may be a factor determining the appearance of contracture in chronic invalids.

VOL. 44 B, NO. 3, AUGUST 1962 
TABLE I

Survey of the Incidence of Dupuytren's Contracture in Three Different Places

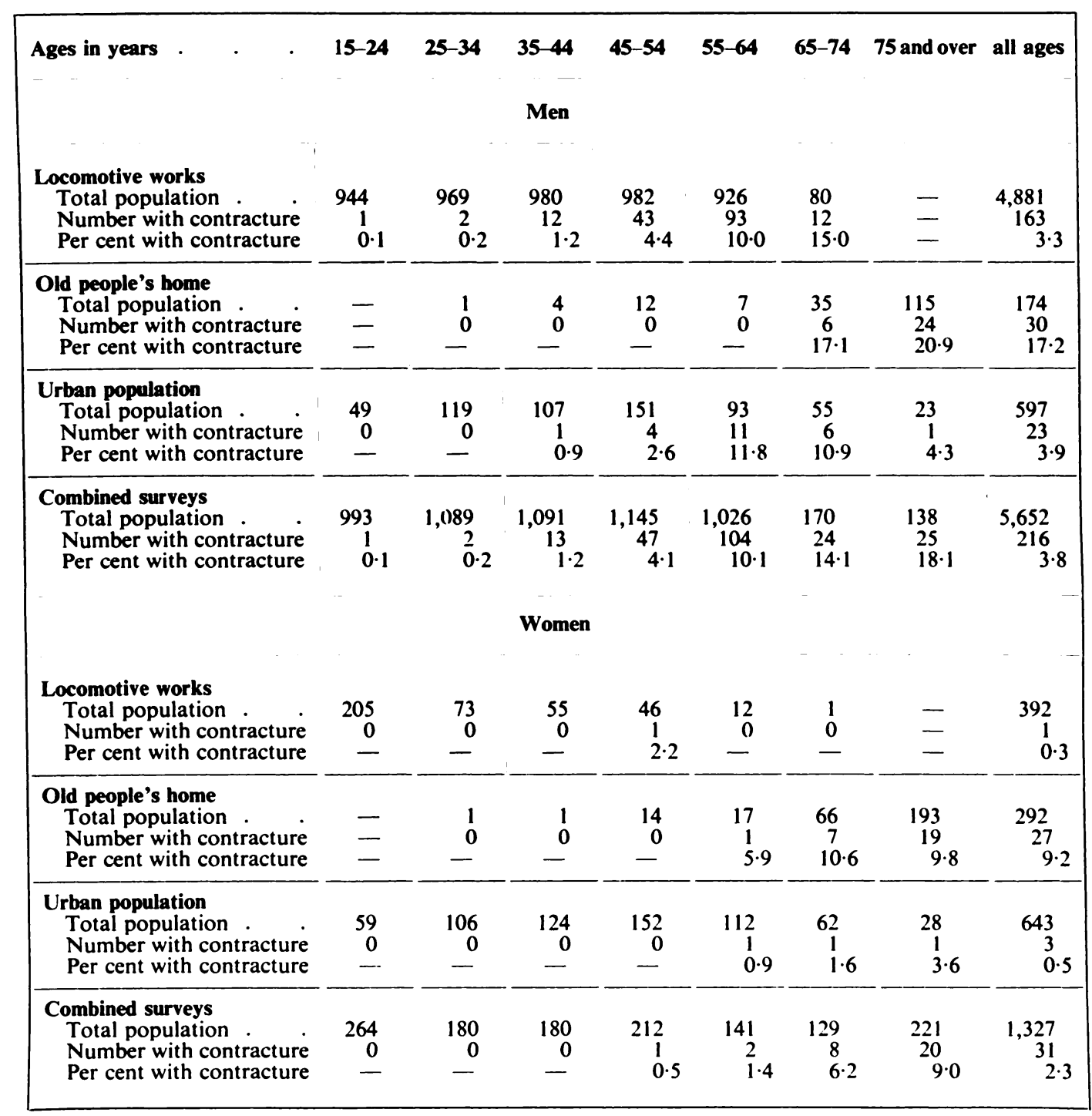

The difference between the incidence in men and women in the combined surveys is highly significant $\left(x^{2}=21.4, \mathrm{P}<0.0001\right)$.

Although occupation thus appears to have no bearing upon the occurrence of Dupuytren's contracture, it could be argued that it might affect its progress and severity. However, if the proportions of Stage 0 hands - that is, those without flexion deformity of any fingers-are compared in various types of occupation (Fig. 4) we see a close similarity between non-manual workers and heavy manual workers, while the highest proportion of mild cases occurs among the intermediate group-those engaged in light work. The differences in the average stage of contracture and in the percentage of bilateral cases between the first and third groups are not statistically significant, and could in any case be explained by the higher average age and longer history in the heavy workers, many of whom continue at work beyond the normal retiring age. The wider disparity - probably significant $(P=0.04)$ - between light and heavy manual workers, as regards the percentages of Stage 0 hands and of bilateral cases, may also in part be accounted 
TABLE II

Dupuytren's Contracture in Mfn at the Crewe locomotive Works Related to Occupation

\begin{tabular}{|c|c|c|c|c|c|c|}
\hline \multirow{2}{*}{ Age in years } & \multicolumn{3}{|c|}{ Office workers } & \multicolumn{3}{|c|}{ Manual workers } \\
\hline & Total & $\begin{array}{l}\text { Number with } \\
\text { contracture }\end{array}$ & Per cent & Total & $\begin{array}{l}\text { Number with } \\
\text { contracture }\end{array}$ & Per cent \\
\hline $15-24$ & 42 & 0 & - & 902 & 1 & $0 \cdot 1$ \\
\hline $25-34$ & 78 & 1 & $1 \cdot 3$ & 891 & 1 & $0 \cdot 1$ \\
\hline $35-44$ & 90 & 3 & $3 \cdot 3$ & 890 & 9 & $1 \cdot 0$ \\
\hline $45-54$ & 110 & 4 & $3 \cdot 6$ & 872 & 39 & $4 \cdot 5$ \\
\hline $55-64$ & 106 & 9 & $8 \cdot 5$ & 820 & 84 & $10 \cdot 0$ \\
\hline $65-74$ & 1 & 0 & - & 79 & 12 & $15 \cdot 2$ \\
\hline Totals for all ages & 427 & 17 & $4 \cdot 0$ & 4,454 & 146 & $3 \cdot 3$ \\
\hline
\end{tabular}

for by the difference in the average length of history (nine and twelve years respectively) for those two groups.

The rarity of Dupuytren's contracture in younger women is brought out by the fact that among more than three hundred women - who were mainly clerical workers-under forty-five, examined at Crewe, not one instance of palmar thickening was found; while only one case was seen in the remaining fifty-nine women, aged forty-five and over.

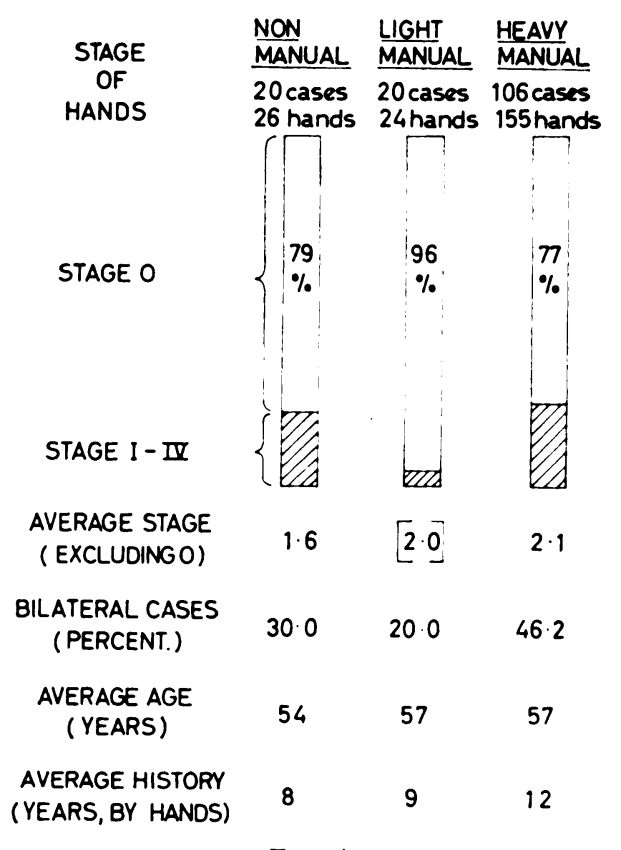

FIG. 4

The degree of contracture in men in three types of occupation at Crewe is compared.

Dupuytren's contracture in the elderly-Because of the obvious predilection of Dupuytren's contracture for the elderly, it was decided to examine the occupants of an old people's home in Manchester (Table I). Similar surveys have, of course, been made in the past, and it is interesting to reflect how little the incidence of this disease has altered since Noble Smith 
gave his figures for London workhouses in 1884 (Table III). In the Manchester survey the proportion of men over eighty-five with palmar contracture rose to 30.8 per cent. The most striking feature, however, is the high figure for women in the older age groups, reducing the preponderance in men to less than two to one.

TABLE III

Dupuytren's Contracture in the Elderly

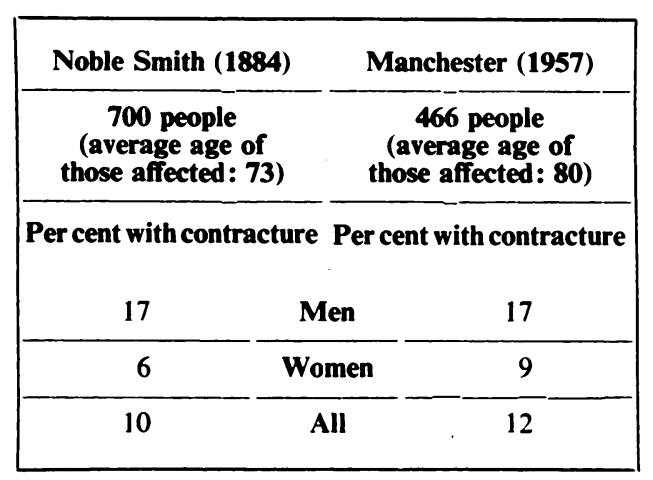

Dupuytren's contracture in an urban population-During recent years random samples from the population of the town of Leigh, including all ages from fifteen onwards, have been investigated for evidence of rheumatic diseases (Kellgren and Lawrence 1956, Lawrence and Bennett 1960). Clinical, radiological and serological examinations were carried out; and amongst other features any changes in the palmar fascia were noted. The frequency of contracture among men at Leigh was 3.9 per cent (Table I); after allowing for disparity in age distribution, this corresponds closely with the total incidence in the Crewe and Manchester surveys. The figure

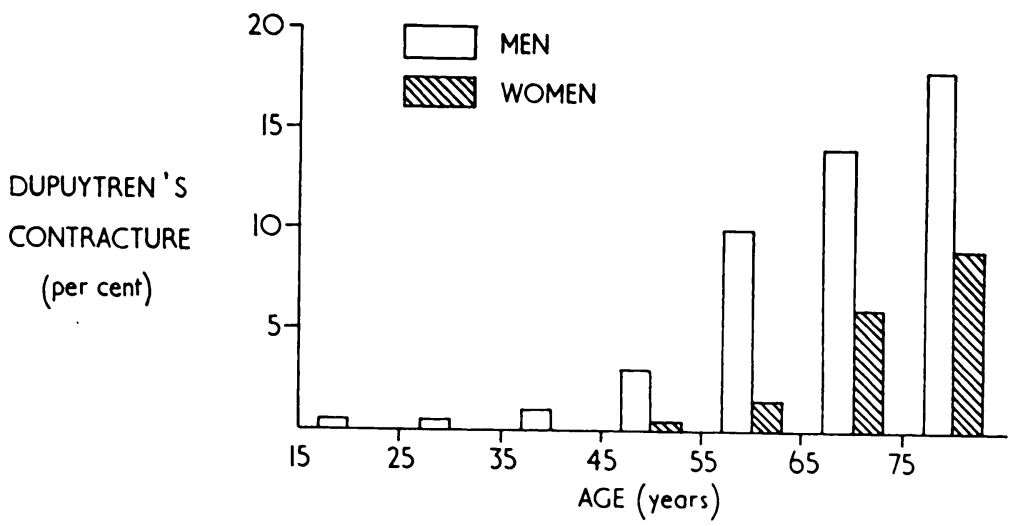

FIG. 5

The combined contracture rate for the three surveys (locomotive works, old people's home, and Leigh).

of 0.5 per cent for women is, however, lower than was to be expected from the previous experience. When the statistics for all three surveys are combined (Table I, Fig. 5) it will be seen that in both sexes there is a steady rise in incidence with age, but that the rise starts later in women and is relatively more rapid, so that the ratio "men to women" diminishes from eight to one in middle age to two to one in those over seventy-five. In more concrete terms, by applying the rates shown in Table I to the adult population of Lancashire and Cheshire (1951 census) we can expect to find one man in twenty-four and one woman in seventy-two with some degree of palmar contracture. 
Dupuytren's contracture and rheumatic disease-As an alternative to chronic injury, a "constitutional vice like gout or rheumatism" (Keen 1882) has often been blamed for Dupuytren's contracture. But the vague term " rheumatism" usually remains undefined, and

TABLE IV

Dupuytren's Contracture and Rheumatic Disease in Men at leigh

\begin{tabular}{|c|c|c|}
\hline \multirow{2}{*}{ Disease } & $\begin{array}{c}\text { In } 23 \text { men with } \\
\text { Dupuytren's contracture }\end{array}$ & In 574 other men \\
\hline & $\begin{array}{c}\text { Standardised rates* } \\
\text { per cent }\end{array}$ & Per cent \\
\hline Clinical rheumatoid arthritis & (0) & $2 \cdot 4$ \\
\hline Radiological rheumatoid arthritis & $7 \cdot 3$ & $7 \cdot 2$ \\
\hline Positive sheep cell agglutination test & $2 \cdot 9$ & $5 \cdot 8$ \\
\hline Previous polyarthritis . & $6 \cdot 4$ & $5 \cdot 0$ \\
\hline One or more osteoarthritic joints & $46 \cdot 1$ & $53 \cdot 5$ \\
\hline Five or more osteoarthritic joints & $6 \cdot 7$ & $7 \cdot 3$ \\
\hline Cervical disc degeneration & $54 \cdot 5$ & $44 \cdot 5$ \\
\hline Cervical osteoarthritis . . . & $13 \cdot 8$ & $10 \cdot 4$ \\
\hline Paget's disease & $1 \cdot 7$ & $2 \cdot 1$ \\
\hline
\end{tabular}

For each disease the difference in percentage between the two groups is less than its standard error. * These rates are to be regarded as relative to those in the second column, and not as absolute values. The same applies to Tables $\mathrm{V}$ and VIII.

TABLE V

Dupuytren's Contracture and Rheumatic Disease

\begin{tabular}{|c|c|c|c|c|}
\hline \multirow{4}{*}{ Clinical rheumatoid arthritis } & & $\begin{array}{c}\text { With } \\
\text { Dupuytren's contracture } \\
\text { (Hospital patients) } \\
314 \text { men } \\
\mathbf{8 4} \text { women }\end{array}$ & $\begin{array}{c}\text { Without } \\
\text { Dupuytren's contracture } \\
\text { (Leigh) } \\
574 \text { men } \\
640 \text { women }\end{array}$ & $\begin{array}{c}\text { With } \\
\text { Dupuytren's contracture } \\
\text { (All patients) } \\
529 \text { men } \\
127 \text { women }\end{array}$ \\
\hline & & $\begin{array}{c}\text { Standardised rates* } \\
\text { per cent }\end{array}$ & Per cent & $\begin{array}{c}\text { Standardised rates* } \\
\text { per cent }\end{array}$ \\
\hline & Men & $1.9(1.0)$ & $2 \cdot 4$ & $1.6(0 \cdot 8)$ \\
\hline & Women & $1.5(1.6)$ & $5 \cdot 8$ & $3.9(2.0)$ \\
\hline \multirow{2}{*}{ Previous polyarthritis } & Men & $4 \cdot 2(1 \cdot 5)$ & $5 \cdot 0$ & $3 \cdot 4(1 \cdot 2)$ \\
\hline & Women & $8 \cdot 6(3 \cdot 2)$ & $7 \cdot 2$ & $8 \cdot 2(2 \cdot 6)$ \\
\hline
\end{tabular}

(Standard errors of the differences in percentage between affected and unaffected groups are shown in brackets.) * These rates are to be regarded as relative to those in the second column, and not as absolute values. The same applies to Tables IV and VIII.

no serious statistical evidence seems to have been produced either for or against the theory. Although the number of men with contracture found at Leigh was small, an attempt has been made to compare the frequency among them of the various diseases covered by that survey, with their frequency in the unaffected male population (Table IV). When allowance is made for the higher age distribution of those affected by contracture, by calculating their standardised rates, these show no significant difference from the control population in regard to the presence 
of rheumatoid arthritis (whether measured clinically, radiologically or by the sheep-cell agglutination test), osteoarthritis, cervical disc degeneration, cervical osteoarthritis, or Paget's disease, or to a past history of polyarthritis.

Taking now the hospital cases of contracture (314 men and eighty-four women) and comparing the rates for clinical rheumatoid arthritis and past polyarthritis with those among the unaffected persons of Leigh (Table V), we find, again, no significant difference, except in the case of rheumatoid arthritis in women, in whom the affected patients show a significantly

TABLE VI

Dupuytren's Contracture in Epileptics at the David Lewis Colony

\begin{tabular}{|c|c|c|c|c|}
\hline \multirow[t]{2}{*}{ Ages in years } & \multirow{2}{*}{$\begin{array}{c}\text { Per cent with } \\
\text { Dupuytren's contracture }\end{array}$} & \multicolumn{3}{|c|}{ Epileptic colony } \\
\hline & & coiving & Expected & Observed \\
\hline \multicolumn{5}{|c|}{ Men } \\
\hline $15-24$ & $0 \cdot 1$ & 37 & 0.037 & 0 \\
\hline $25-34$ & $0 \cdot 2$ & 38 & 0.076 & 2 \\
\hline $35-44$ & $1 \cdot 2$ & 27 & 0.324 & 3 \\
\hline $45-54$ & $4 \cdot 1$ & 34 & $1 \cdot 394$ & 5 \\
\hline $55-64$ & $10 \cdot 1$ & 23 & $2 \cdot 323$ & 6 \\
\hline 65 and over & $15 \cdot 9$ & 8 & $1 \cdot 272$ & 2 \\
\hline Total for all ages & & 167 & $5 \cdot 426$ & 18 \\
\hline \multicolumn{5}{|c|}{ Women } \\
\hline $15-24$ & $\mathbf{0}$ & 30 & 0 & 0 \\
\hline $25-34$ & 0 & 33 & $\mathbf{0}$ & 2 \\
\hline $35-44$ & $\mathbf{0}$ & 37 & 0 & 0 \\
\hline $45-54$ & 0.5 & 56 & 0.280 & 5 \\
\hline $55-64$ & $1 \cdot 4$ & 26 & 0.364 & 2 \\
\hline 65 and over & $8 \cdot 0$ & 16 & $1 \cdot 280$ & 5 \\
\hline Total for all ages & & 198 & $1 \cdot 924$ & 14 \\
\hline
\end{tabular}

For each sex the difference between the incidence of contracture in epileptics and that in the control population is highly significant. (For males, $x^{2}=29 \cdot 2, \mathrm{P}<0.0001$.)

* 23 boys and 13 girls (all contracture-free) in age group 5-14 are excluded from this Table.

lower incidence than do the controls. Much of this discrepancy disappears, however, if all affected cases-including those from the surveys-are analysed (third column of Table V). The other diseases investigated at Leigh depended for their diagnosis to a large extent on routine radiological examination, and for them therefore no comparison can be made with the hospital cases, in which radiographs were not routinely employed.

Dupuytren's contracture and epilepsy-Lund in 1941 was the first to draw attention to the abnormally high incidence of Dupuytren's contracture among epileptic patients in Scandinavia, and his observations have been confirmed by Skoog (1948), Arieff and Bell (1956) in America, and Hueston (1960) in Australia; Gordon (1954), however, from Canada, reported less 
contracture in epileptics than in the general hospital population. Examination of 401 patients at the David Lewis epileptic colony, Warford, revealed an overall contracture rate of 8 per cent, despite the large proportion of young people in the colony (Table VI, Fig. 6). Remarkable also is the frequency among women, giving a ratio of only three men to two women. For each sex the increase over the incidence already shown in the general population is highly significant.

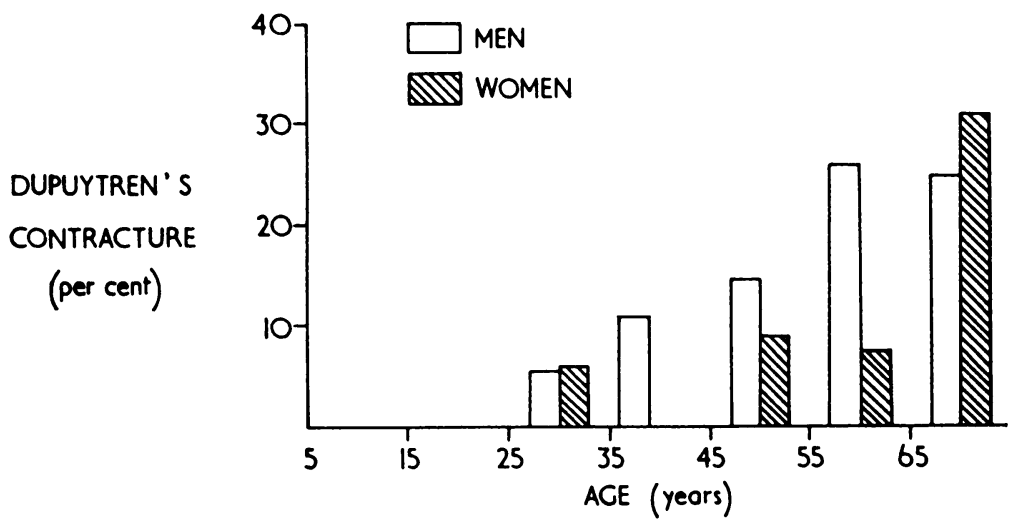

FIG. 6

Incidence of Dupuytren's contracture in 401 epileptic patients at the David Lewis colony.

This relationship may be viewed from another angle by counting the number of epileptics among our cases of contracture, excluding colony patients and others who have presented primarily in connection with their epilepsy. Of the 620 cases thus eligible for analysis, twentyfive gave a history of epilepsy, and eighteen of these had suffered severe attacks. Taking account of severe epilepsy alone, we find (Table VII) that the incidence for men is five times greater, and for women eleven times greater, than the commonly accepted figure of one in 200 for epilepsy in the general population (Fairfield 1954).

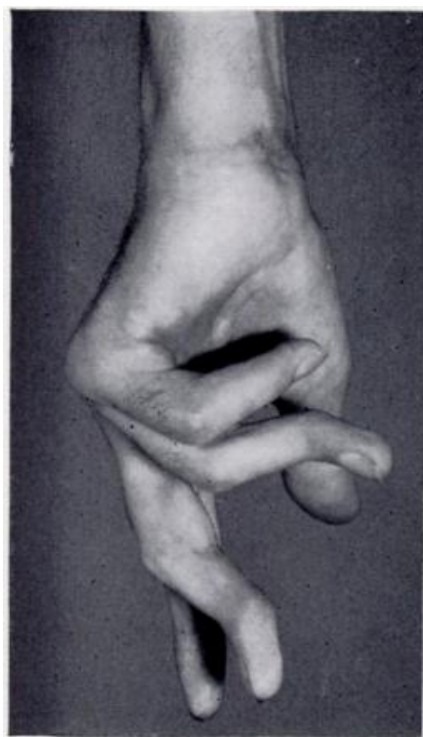

Fig. 7

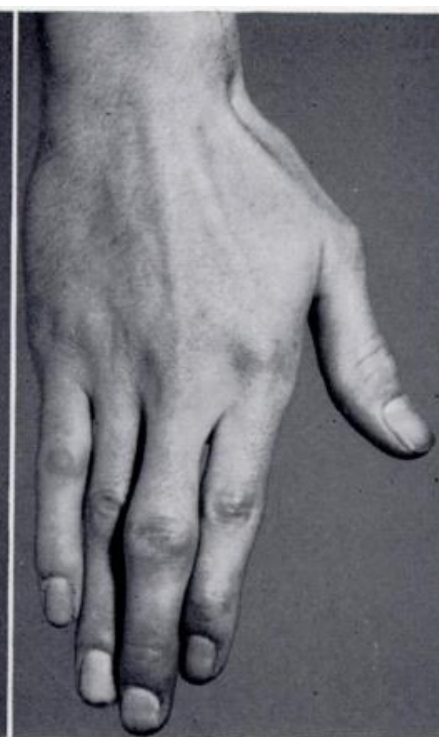

Fig. 8

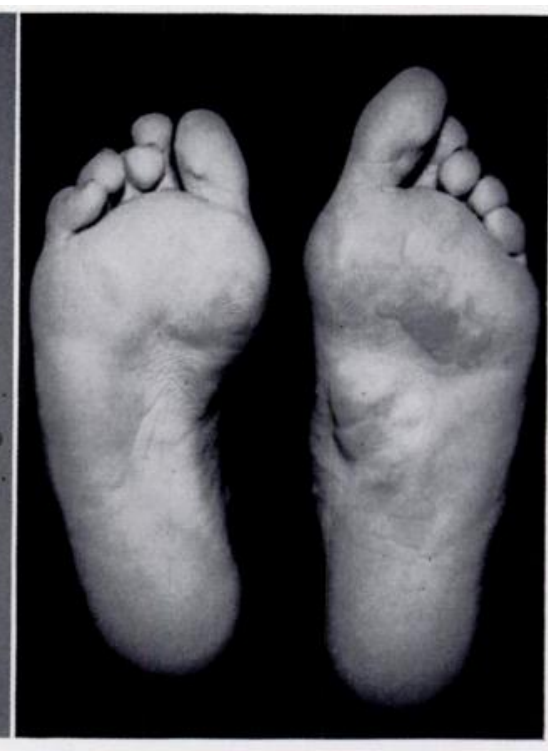

Fig. 9

A man aged thirty-one years. Figure 7-Stage IV deformity of left hand. Figure 8-Knuckle pads over proximal interphalangeal joints of right hand. Figure 9-Bilateral plantar nodules. The patient gave a history of contracture in his maternal grandfather.

VOl. 44 B, No. 3, AUGUST 1962 
With Dupuytren's contracture in general there is a strong statistical association between knuckle-pads and the plantar nodules of Ledderhose, and a less certain association between these and a history of contracture in near relatives-exemplified in Figures 7 to 9. Lund (1941) recorded an exceptionally high frequency of knuckle-pads (helodermia) among epileptic patients with palmar contracture, as well as a striking incidence of plantar nodules and of periarthritis of the shoulder in these patients. However, his figures for knuckle-pads and

TABLE VII

Relationship of EPILEPSY to DUPUytRen's Contracture

\begin{tabular}{|c|c|c|c|c|}
\hline & & Men & Women & Total \\
\hline Number of people with Dupu & s contracture & 509 & 111 & 620 \\
\hline Number of severe epileptics & . & 12 & 6 & 18 \\
\hline Percentage with epilepsy & . & $2 \cdot 4$ & $5 \cdot 4$ & $2 \cdot 9$ \\
\hline
\end{tabular}

TABLE VIII

InCIDENCE of Various Factors in Dupuytren's Contracture and EPILePSy

\begin{tabular}{|c|c|c|c|}
\hline \multirow{5}{*}{ Knuckle pads . } & & $\begin{array}{l}\text { With Dupuytren's contracture } \\
\text { and epilepsy }\end{array}$ & $\begin{array}{l}\text { With Dupuytren's contracture } \\
\text { alone }\end{array}$ \\
\hline & & 37 men 24 women & 492 men 103 women \\
\hline & & $\begin{array}{l}\text { Standardised rates* } \\
\text { per cent }\end{array}$ & Per cent \\
\hline & Men & $31 \cdot 4$ & $21 \cdot 3$ \\
\hline & Women & $19 \cdot 3$ & $12 \cdot 6$ \\
\hline \multirow{2}{*}{ Plantar nodules } & Men & 16.9 & 6.9 \\
\hline & Women & $10 \cdot 2$ & $3 \cdot 9$ \\
\hline \multirow{2}{*}{ Periarthritis of the shoulder } & Men & $10 \cdot 9$ & $6 \cdot 5$ \\
\hline & Women & $11 \cdot 0$ & $9 \cdot 7$ \\
\hline \multirow{2}{*}{ Family history. } & Men & $5 \cdot 4$ & $14 \cdot 8$ \\
\hline & Women & $8 \cdot 2$ & $12 \cdot 6$ \\
\hline \multirow{2}{*}{ Bilateral contractures } & Men & $68 \cdot 3$ & $59 \cdot 6$ \\
\hline & Women & $95 \cdot 7$ & $57 \cdot 3$ \\
\hline \multirow{2}{*}{ Symmetry in bilateral cases } & Men & $45 \cdot 8$ & $30 \cdot 4$ \\
\hline & Women & $74 \cdot 1$ & $40 \cdot 7$ \\
\hline
\end{tabular}

* These rates are to be regarded as relative to those in the second column, and not as absolute values. The same applies to Tables IV and V.

plantar nodules in non-epileptic persons with contracture were remarkably low. The present series shows a preponderance of all three lesions in patients with Dupuytren's contracture and epilepsy, as seen in Table VIII. It is at first sight surprising that so small a proportion of the epileptics gave a positive family history of contracture. In colony patients this can perhaps be explained by separation from their families, and in many epileptics by defective memory. Similar considerations probably account for the sharp drop in frequency of a positive family history after the age of sixty-five found in Dupuytren's contracture as a whole. Moreover, since many of the epileptic cases were discovered by survey, they include a rather high 
proportion of milder degrees of contracture, and it can be shown that the chance of obtaining a positive family history increases with the stage of contracture. At least in part, this is probably because of the greater attention paid by the patient and his relatives to a severely deformed hand than to one in an early stage of contracture, which may even be overlooked altogether.

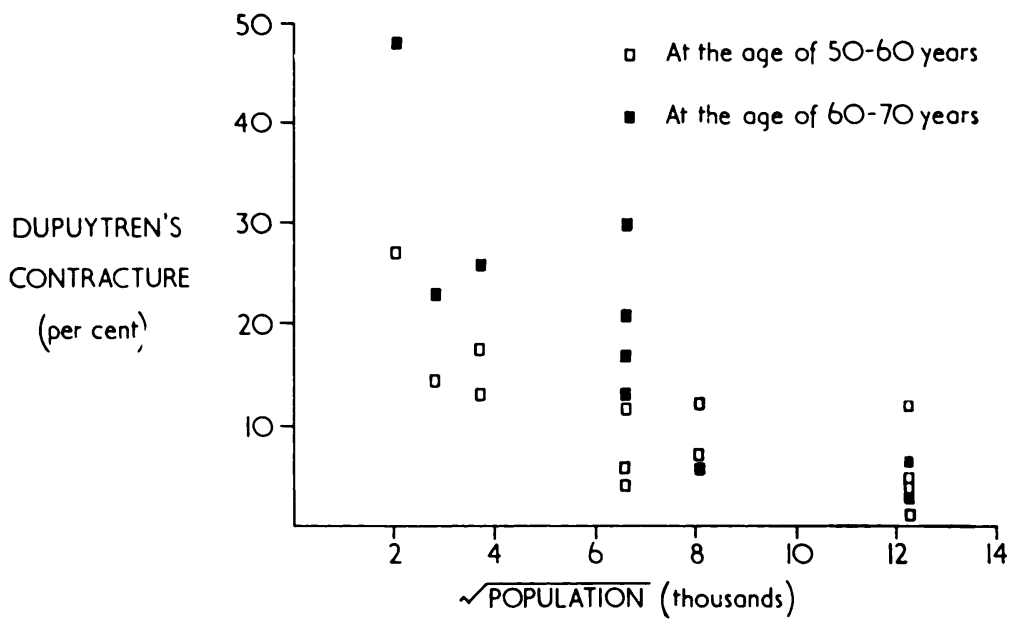

FiG. 10

The relationship between incidence of Dupuytren's contracture in men and the population in six countries. Population figures are for 1945-51, of which the square roots have been used for convenience in charting. Each white square represents an estimate for the average age of fifty to sixty; each black square, for the average age of sixty to seventy. Correlations are significant (for white squares, $\mathrm{P}<0.05$; for black squares, $\mathrm{P}<0.01$ ).

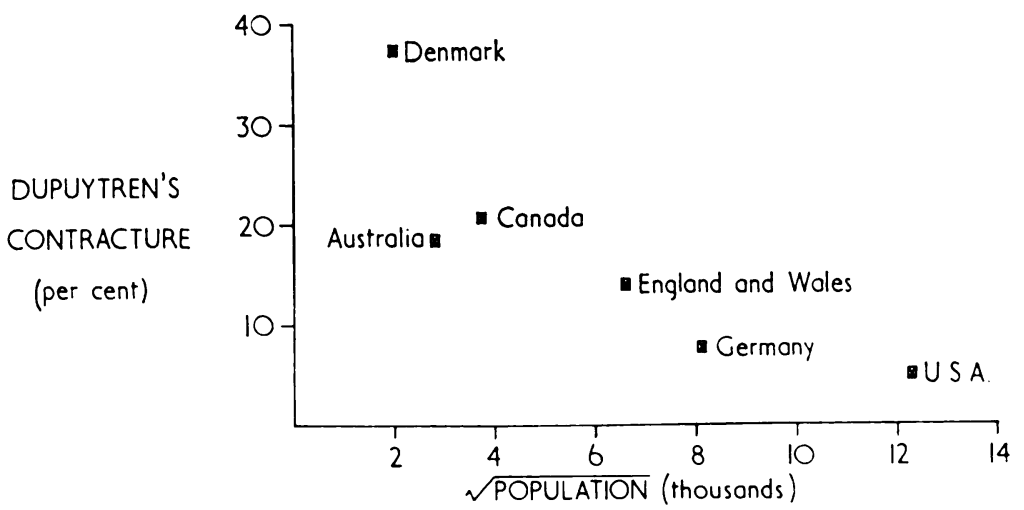

Fig. 11

Relationship between average incidence of Dupuytren s contracture in men and the population in six countries. The findings in Figure 10 have been averaged for each country to give an estimated incidence at the age of sixty. Correlation is significant $(P<0.05)$.

Perhaps also cases with a strong hereditary element tend to run a more rapid course, and thus, on average, reach a more advanced stage than those without; but so far the evidence does not support this.

Table VIII shows also that the epileptic patients include a higher percentage of bilateral contractures than do the non-epileptic; and of the bilateral ones, a higher proportion show a symmetrical pattern of contracture in the two hands, the differences in women being statistically significant. All these features taken together indicate a stronger constitutional 
factor in persons with both Dupuytren's contracture and epilepsy than in persons with either of those conditions alone. The nature of this factor remains obscure. It is most probably genetic in origin; but one cannot exclude the possibility of an extraneous influence-such as the administration of phenobarbitone-as suggested by Lund.

\section{GEOGRAPHICAL DISTRIBUTION}

As stated earlier, only a small number of reports have provided data sufficient to enable one to compare the incidence of Dupuytren's contracture in various parts of the world. Even such roughly comparable statistics differ widely among themselves, and it seems clear that this is at least partly because of a real variation in frequency of the contracture from country to country. The disease is recognised to be rare in the negro and in oriental races; but striking differences also appear among peoples of European origin, as is shown in Figures 10 and 11, in which are charted the estimates for men of average age between fifty and seventy, taken from eighteen sources* in the six countries named. It is of interest that contracture tends to be more prevalent in countries with smaller populations: whether this represents a true relationship or is purely fortuitous could only be decided by extensive and adequately controlled surveys in many more countries. If one postulates the condition as having arisen in one particular racial group (the Nordic, for example) then the variable distribution in other parts of the world might be explained on the basis of migration from that group. Such migration would lead to greater or lesser dilution of the gene for contracture, according to the population size of the host country - a large population producing low frequency of the gene; but should the original immigrants to a "new" country happen to have possessed the gene for contracture in high degree-either because they came from a "Dupuytren-prone" race or (where their number was small) simply by chance-this would account for a high prevalence of contracture among their descendants.

\section{SUMMARY AND CONCLUSIONS}

1. Surveys of a working community, of a group of elderly people, and of an urban population show an incidence of Dupuytren's contracture among men varying from 0.1 per cent in the age group fifteen to twenty-four, to 18.1 per cent in those aged seventy-five and over; and among women from 0.5 per cent in the age group forty-five to fifty-four, to 9 per cent over seventy-five. It is estimated that in the population aged fifteen and over in Lancashire and Cheshire there will be 4.2 per cent of the men and 1.4 per cent of the women with some degree of palmar contracture.

2. There appears to be no relationship between the type of occupation and the incidence or severity of contracture in men, except that among those engaged in light manual work the proportion of mildly affected hands is higher, and of bilateral contracture lower, than among either non-manual or heavy manual workers.

3. Evidence is provided that rheumatoid arthritis, past polyarthritis, osteoarthritis, cervical spondylosis and Paget's disease occur no more often in those with Dupuytren's contracture than in other members of the community.

4. Examination of the patients in an epileptic colony confirms a strong association between Dupuytren's contracture and epilepsy. Knuckle-pads, plantar nodules and periarthritis of the shoulder are all more frequent in epileptic than in non-epileptic patients with Dupuytren's contracture. Epileptics also show a higher proportion with bilateral contractures and a greater tendency to a symmetrical pattern of contracture in the two hands. A strong constitutional factor, probably genetic, thus operates in persons with both diseases.

* Smith (1884), Nichols (1899), Collis and Eatock (1912), Black (1915), Byford (1921), Davis and Finesilver (1932), Niederland (1933), Schröder (1934), Gerritzen (1936), Smith and Masters (1939), Lund (1941), Ayre (1946), Herzog (1951), Gordon (1954), Yost, Winters and Fett (1955), Wolfe, Summerskill and Davidson (1956), Hueston (1960), Early (1962) (present communication). 
Nevertheless, the frequency of a positive family history of contracture is lower in the epileptic cases, and reasons for this are discussed.

5. From the limited material available in the literature there would appear to be an inverse relationship between the population of certain countries and the prevalence in them of Dupuytren's contracture. The possible significance of this is briefly discussed.

I wish to thank Mr D. Lloyd Griffiths for advice and encouragement during the research, and for reading and criticising the manuscript of this paper. I am indebted to Mr John Charnley and to consultants in many hospitals for allowing me to examine patients under their care; to Dr C. Leith-Barron and the Management of the British Railways locomotive works at Crewe, to the City of Manchester Welfare Services Department, and to Dr Richard Handley, for help in arranging the surveys; and to Professor J. H. Kellgren, Dr J. S. Lawrence and the Empire Rheumatism Council for giving me access to statistical results of the Leigh survey and to the patients with Dupuytren's contracture found at Leigh. My thanks are also due to Dr J. N. Hartshorne for advice on genetic aspects, to Miss I. D. Fordyce for help with statistics, and to Dr Robert Ollerenshaw and his staff for the photographs.

The material for this study was collected during the tenure of a research fellowship in orthopaedics at the Manchester Royal Infirmary, granted by the Board of Governors of the United Manchester Hospitals.

\section{REFERENCES}

Arieff, A. J., and Bell, J. (1956): Epilepsy and Dupuytren's Contracture. Neurology, 6, 115.

AYre, W. B. (1946): Dupuytren's Contracture. Canadian Medical Association Journal, 54, 158.

BlACK, K. (1915): Dupuytren`s Contraction. British Medical Journal, i, 326.

Byford, W. H. (1921): The Pathogenesis of Dupuytren's Contraction of the Palmar Fascia. Medical Record, $100,487$.

Collis, E. L., and EATOCK, R. (1912): Report of an Inquiry on Dupuytren's Contraction as a Disease of Occupation, with Special Reference to its Occurrence among Minders of Lace Machines. London: His Majesty's Stationery Office.

Davis, J. S., and Finesilver, E. M. (1932): Dupuytren's Contraction, with a Note on the Incidence of the Contraction in Diabetes. Archives of Surgery, 24, 933.

DupUYTRen, Baron G. (1832): Leçons orales de clinique chirurgicale, Vol. I, Article I. Paris: Germer-Baillière.

Fairfield, L. (1954): Epilepsy-Grand Mal, Petit Mal, Convulsions, p. 30. London: Gerald Duckworth \& Co. Ltd.

GeRRITZEN (1936): Operationserfolge der Dupuytren'schen Kontraktur unter Berücksichtigung der unfallsweisen Entstehung. Zentralblatt für Chirurgie, 63, 161.

Gordon, S. (1954): Dupuytren's Contracture: the Significance of Various Factors in its Etiology. Annals of Surgery, 140, 683.

Herzog, E. G. (1951): The Aetiology of Dupuytren's Contracture. Lancet, i, 1,305.

Hueston, J. T. (1960): The Incidence of Dupuytren`s Contracture. Medical Journal of Australia, ii, 999.

KefN, W. W. (1882): The Etiology and Pathology of Dupuytren's Contraction of the Fingers. Philadelphia Medical Times, 12, 370.

Kellgren, J. H., and Lawrence, J. S. (1956): Rheumatoid Arthritis in a Population Sample. Annals of the Rheumatic Diseases, 15, 1.

Lawrence, J. S., and Bennett, P. H. (1960): Benign Polyarthritis. Annals of the Rheumatic Diseases, 19, 20.

Lund, M. (1941): Dupuytren's Contracture and Epilepsy. Acta Psychiatrica et Neurologica, 16, 465.

Nichols, J. B. (1899): A Clinical Study of Dupuytren's Contraction of the Palmar and Digital Fascia. American Journal of the Medical Sciences, 117, 285.

Niederland, W. (1933): Dupuytren'sche Kontraktur und Beruf. Zentralblatt für Chirurgie, 60, 985.

SCHRöDER, C. H. (1934): Berufsarbeit und Trauma bei der Dupuytrenschen Kontraktur. Deutsche Zeitschrift für Chirurgie, 244, 140.

Skoog, T. (1948): Dupuytren's Contraction with Special Reference to Aetiology and Improved Surgical Treatment. Its Occurrence in Epileptics. Note on Knuckle-pads. Acta Chirurgica Scandinavica, 96, Supplementum 139.

Smith, K. D., and MASTERS, W. E. (1939): Dupuytren's Contraction Among Upholsterers. Journal of Industrial Hygiene and Toxicology, 21, 97.

Sмітн, N. (1884): Seventy Cases of Dupuytren`s Contraction of the Fingers. British Medical Journal, i, 603.

Wolfe, S. J., Summerskill, W. H. J., and Davidson, C. S. (1956): Thickening and Contraction of the Palmar Fascia (Dupuytren's Contracture) Associated with Alcoholism and Hepatic Cirrhosis. New England Journal of Medicine, 255, 559.

Yost, J., Winters, T., and Fetr, H. C., Sen. (1955): Dupuytren's Contracture. A Statistical Study. American Journal of Surgery, 90, 568.

VOL. 44 B, NO. 3, AUGUST 1962 